with the lamprophyres, the series ranging from modified biotiteporphyrites to modified pilitic lamprophyres.

The later intrusions are typically free from the large orthoclasefelspars, though quartz-grains mav occur even in the basic members. Associated centrally with the earlier set they are distributed over a much wider area, overlapping the former in every direction. They are the result of further differentiation, and are assigned to a later period when igneous activity was renewed on a more or less regional scale. The rocks include acid felsites and spessartites.

The rocks of the earlier set agree in general direction with the north-north-west fractures transverse to the strike of the country rock, while the later intrusions trend generally east of north.

\title{
V.-Geologists' Association.
}

December 1, 1917.-George Barrow, F.G.S., President, in the Chair.

The following lecture was delivered: "The Gold Coast." By Albert Ernest Kitson, F.G.S., Director of the Geological Survey of the Gold Coast.

The features to be considered, after a general description of the geography and tectonics of the colony, are: the Archæan gneisses, schists, amphibolites, ete., principally of the Eastern Provinces; the folded and zonally contorted pre-Cambrian, or early Palæozoic, altered sediments (conglomerates, quartzites, etc.), with interbedded volcanic rocks (rhyolite, andesite), flanking the former group and extending westward across the colony; deposits of gold and manganese.

Intrusions (into both groups) of granites, syenites, diorites, gabbros, etc.; dolerite volcanic necks; gold, tin, ilmenite, and molybdenite associated with these rocks.

The slightly inclined sedimentary rocks of the coast (with Devonian fossils) and of the greater part of A shanti and the Northern Provinces with bauxites, oil-shales, and clays; the Tertiary deposits of Apollonia with bitumen and oil, the "laterites" and associated iron-ores. Fluviatile, estuarine, and æolian deposits.

The evidence of aboriginal occupation, consisting of stone-implement factories, camps, and crude forts, was also discussed.

\section{OORRESPONDEINOE.}

\section{WORM-BORINGS IN ROCKS.}

SIR,-Dr. Bather's interesting communication on "Salt-weathering and supposed Worm-borings in Australia" (GEoL. MAG., November, 1917 ) induces me to direct attention to a paper read by the late Duke of Argyll before the Royal Society of Edinburgh in January, 1889. In this he described similar tubes occurring in some of the quartzites of Sutherlandshire, and which he and the late Vr. Etheridge attributed to the burrowing of annelids. Some of these tubes were horizontal, having been drawn out of the rertical by movements due to shearing or slipping of the beds or laminæ of the deposit. 
In a communication entitled "Pseudo-Scolites" (Research, April 1, 1889) I pointed out that such tubes or "foralites" might be seen in great numbers on sloping, sandy beaches, especially when the sand covers a deposit of shingle, and that they were simply vents formed in the wet sand by the escaping air, which was compressed by the advancing waves. In a given slope of shingle, covered with a layer of wet sand, there is a certain quantity of air, and this, on being compressed by an advancing wave, escapes through the wet sand at the surface. The advance of the wave increases the pressure, and the confined air escapes from the weakest points at the surface of the sand. From the rents thus produced the air issues with considerable energy, as bubbles forced through the water of a retreating wave often show. The receding tide leaves many of these miniature blowholes intact, and frequently with a crater-like ridge of sand around their orifices. In some cases these tubes were 4 or 5 inches in depth, and on the more level parts of a beach where firm sand prevailed they were filled up with fine mud, Foraminifera, and minute fragments of shell, etc. Under favourable circumstances these tubes might be preserved from future obliteration.

Such tubes might also be formed in unindurated inland deposits by the escape of compressed gases caused by the decomposition of organic matter, chemical reactions, and by steam escaping from heated areas.

altmore, Waldegrave Park, STRA WBERRY HILL.

C. Carus-Wilson. November 13, 1917.

Note By Dr. Bather.

I must apologise for having omitted all reference to Dr. CarusWilson's previously published obervations, due, I regret to say, to pure ignorance of them on my part and presumably also on the part of Professor Högbom, with whose account they entirely agree. The pipe-rock of Sutherland is so well known to British geologists that it was hardly necessary for me to mention it. Dr. Carus-Wilson's reference to it is apparently intended to suggest that the horizontal position of some of the tubes in the Tasmanian rocks may be due to subsequent movement. On this point $I$ have no evidence.

F. A. Bather.

\section{BORING FOR COAL AT PRESTEIGN.}

SIr,-The alleged discovery of buried stores of coal at the Presteign lime-kilns, suggested by Professor Watts (Groc. MaG., 1917 , p. 552) as the origin of the local delusion that a bed of coal crops out there, is a possible explanation; but it is remarkable and lamentable that no tradition of the lime-burning survived among the unfortunate subscribers. Some such storing of fuel may account also for the local belief in the existence of coal at Cadwell, 3 miles E.N.E. of Presteign, where pieces of coal in the soil above a quarry in Wenlock mudstones and nodular limestones (containing the usual fossils) were visible in 1915. The coal may have been taken there to burn lime at some remote period. 